\title{
Pengaruh Pemberian Sediaan Creambath Ekstrak Daun Kembang Sepatu (Hibiscus Rosa-Sinensis) pada Pertumbuhan Rambut Kelinci (New Zealand)
}

\section{Influence The Granting of Material-Extracts of Hibiscus Leaves (Hibiscus Rosa-Sinensis) on The Growth of Rabbit Hair (New Zealand)}

\author{
Lita Widyastuti ${ }^{1 *}$, Dwi Ningsih², Siti Aisiyah ${ }^{3}$ \\ Litawidyastuti72@gmail.com \\ ${ }^{1}$ Faculty of Pharmacy, University of Setia Budi, Jl. Letjen Sutoyo-Mojosongo Surakarta, 57127, \\ Indonesia
}

\begin{abstract}
Abstrak
Kembang sepatu mengandung flavonoid, saponin dan polifenol yang berperan dalam mempercepat pertumbuhan rambut. Penelitian ini bertujuan untuk mengetahui pengaruh variasi konsentrasi ekstrak etanol daun kembang sepatu dalam sediaan creambath terhadap pertumbuhan rambut kelinci. Ekstrak etanol daun kembang sepatu diperoleh dengan metode remaserasi menggunakan etanol $70 \%$. Sediaan creambath dibuat dalam 4 formula dengan konsentrasi ekstrak kembang sepatu sebanyak $10 \%, 15 \%$, $20 \%$ dan kontrol negatif. Creambath diaplikasikan ke punggung kelinci yang telah dicukur kemudian diberi sediaan creambath 2 kali sehari selama 15 hari. Uji aktivitas pertumbuhan rambut kelinci dengan mengukur panjang rambut dan bobot rambut kelinci, serta dilakukan uji fisiknya yang meliputi bau, warna, pH, daya sebar, daya lekat, kemampuan proteksi, viskositas, tipe krim, dan stabilitas creambath. Data uji mutu fisik, bobot, dan rambut dianalisis dengan Saphiro-Wilk, kemudian menggunakan ANOVA dan Post Hoc Tests. Hasil penelitian menunjukkan bahwa sediaan creambath ekstrak etanol daun kembang sepatu dengan konsentrasi $10 \%$, 15\%, dan $20 \%$ memilki stabilitas fisik yang baik. Semakin tinggi konsentrasi ekstrak dalam sediaan creambath menghasilkan perbedaan aktivitas pertumbuhan rambut kelinci. Hasil dilihat dari parameter bobot dan panjang rambut, tetapi belum bisa seefektif kontrol pembanding. Formula creambath yang memberikan hasil efektif terhadap pertumbuhan rambut kelinci adalah creambath dengan konsentrasi $20 \%$.
\end{abstract}

Kata kunci : creambath, daun kembang sepatu, ekstrak, rambut, formula

\begin{abstract}
Hibiscus rosa-sinensis is contains flavonoids, saponins and polyphenols that play a role in accelerating the growth of hair. This research aims to know the influence of the variation of concentration of ethanol extracts of hibiscus leaves in preparation creambath against rabbit hair growth. Of ethanol extracts of hibiscus leaves are obtained with the method remaseration using ethanol $70 \%$. Creambath preparation made in 4 formula with the concentration of the extract of hibiscus in 10\%,15\%,20\% and a negative control. Applied to the backs of rabbits that had been shaved and then given the preparations-2 times a day for 15 days. To test the activity of rabbit hair
\end{abstract}


growth by measuring the length of the hair and rabbit hair, weight and physical test performed which include odor, color, $\mathrm{pH}$, spread power, power protection, the ability to say, type, viscosity and stability of creams, creambath. Physical quality test data, weight, and hair is analyzed with the Saphiro-Wilk, then using ANOVA and Post Hoc Tests. The results showed that preparations creambath hibiscus leaves ethanol extract with a concentration of $10 \%, 15 \%$, and $20 \%$ have good physical stability. The higher the concentration of the extract in preparations creambath hair growth activity differences produce rabbits. The results views of the parameter weights and lengths of hair, but not yet as effective as comparison control formula that delivers results-effective against the growth of rabbit hair creambath is with a concentration of $20 \%$.

\section{Keywords: creambath, hibiscus leaves, extracts, hair, formula}

\section{Pendahuluan}

Rambut mempunyai arti penting dalam kehidupan manusia, rambut tumbuh hampir pada seluruh tubuh dan memiliki fungsi, antara lain untuk melindungi kulit dari gangguan luar yang merugikan. Rambut mengalami siklus pertumbuhan dan kerontokan yang berbeda setiap helainya. Kerontokan merupakan siklus dalam pertumbuhan rambut, kerontokan dengan jumlah 60-100 helai perhari merupakan kerontokan yang masih dianggap wajar, tetapi frekuensi jumlah kerontokan yang meningkat atau kerontokan melebihi batas normal dapat mengakibatkan kebotakan.

Kembang sepatu secara tradisional diyakini memiliki aktivitas dapat memacu pertumbuhan rambut yaitu bunga dan daun kembang sepatu (Hibiscus rosa-sinensis) (Kumar \& Singh 2012; Pathan et al 2012). Daun dan bunga kembang sepatu kaya akan flavonoid, dimana komponen utama daun dan bunga kembang sepatu adalah antosianin dan flavonoid, sianidin-3,5-diglukosida, sianidin-3sophorosida-5-glukosida, kuersetin-3-7diglukosida, dan kuersetin-3-diglukosida (Jadhav et al. 2009). Hasil penelitian (Amelia et al. 2016) membuktikan bahwa ekstrak etanol daun kembang sepatu lebih poten merangsang pertumbuhan rambut dibandingkan dengan ekstrak etanol bunga kembang sepatu yang dibuat dalam sediaan hair tonik.

Kadar flavonoid yang terkandung dalam daun kembang sepatu diduga mempunyai aktivitas sebagai bakterisid yang dapat menekan pertumbuhan bakteri sehingga dapat mempercepat pertumbuhan rambut dan mencegah kerontokan. Senyawa saponin dapat membentuk busa yang berarti mampu membersihkan kulit dan kotoran serta sifatnya sebagai counteriritan dan polifenol sebagai keratolitik yaitu mencegah pengerasan kulit kepala dan merangsang pelepasan stratum corneum sehingga akan merangsang pertumbuhan rambut (Yuswantina et al. 2013).

Berdasarkan potensi daun kembang sepatu sebagai penyubur rambut, maka perlu pengembangan sediaan lain yang memiliki nilai lebih dibandingkan dengan sediaan sebelumnya. Ekstrak daun kembang sepatu dibuat dalam bentuk sediaan creambath karena dalam mengatasi masalah pada rambut tidak hanya menggunakan shampo dan hair tonik saja yang digunakan untuk memperbaiki atau mengatasi masalah pada rambut. Creambath mengandung nutrisi penting yang sangat dibutuhkan oleh rambut. Creambath memiliki keunggulan yaitu mudah dicuci, penggunaan mudah, dapat menembus kulit kepala, penggunaannya yang mudah dan tidak lengket sehingga tidak meninggalkan kerak atau lapisan tipis yang dapat memicu terbentuknya ketombe. Bahan-

bahan formula yang digunakan juga dapat membantu zat aktif diabsorbsi lebih baik di dalam rambut, sehingga dapat mempercepat pertumbuhan rambut. Pengujian pengaruh pemberian creambath ekstrak daun kembang sepatu (Hibiscus rosa-sinensis L) terhadap pertumbuhan rambut dilakukan dengan uji farmakologi pada hewan uji kelinci.

\section{Metode}

Bahan

Isopropil miristat, propil paraben, metil paraben, setrimonium klorida, stearath20, natrium metabisulfit, creambath dengan khasiat yang sama yang beredar di pasaran sebagai kontrol positif, kelinci new realand. 


\section{Jalannya Penelitian}

\section{Pembuatan ekstrak daun kembang sepatu}

Pembuatan ekstrak etanol dengan cara

500 gram serbuk daun kembang sepatu, kemudian dimasukkan ke dalam botol coklat yang terhindar dari cahaya, lalu ditambah dengaan etanol $70 \%$ sebanyak $3750 \mathrm{~mL}$, kemudian tutup. Maserasi dilakukan kurang lebih selama 5 hari dengan penggojogan atau dengan sering diaduk. Setelah 5 hari, disaring dengan kain flanel dan diperas. Maserat dimasukkan kedalam botol coklat yang bersih. Kemudian ampas diremaserasi selama 2 hari dengan ditambahkan etanol $70 \%$ sebanyak
$1250 \mathrm{~mL}$. Kemudian disaring dengan kain flanel, maserat dijadikan satu dengan maserat yang pertama. Maserat yang didapat dipekatkan dengan rotary evaporator (suhu tetap dijaga pada $40^{\circ} \mathrm{C}-50^{\circ} \mathrm{C}$ ) sampai diperoleh ekstrak kental. Hasil inilah yang selanjutnya disebut sebagai ekstrak etanol daun kembang sepatu (Hibiscus rosa-sinensis $L$.).

\section{Formula creambath ekstrak etanol daun kembang sepatu}

Formula creambath ekstrak etanol daun kembang sepatu dapat dilihat pada tabel.

Tabel 1. Formula creambath ekstrak etanol daun kembang sepatu dengan berbagai konsentrasi ekstrak kental (Teti et al. 2018)

\begin{tabular}{lcccc}
\hline \multirow{2}{*}{ Bahan } & \multicolumn{4}{c}{ Konsentrasi bahan $(\%)$} \\
\cline { 2 - 5 } & $\mathrm{F} 1$ & $\mathrm{~F} 2$ & $\mathrm{~F} 3$ & $\mathrm{~F} 4$ \\
\hline Ekstrak daun kembang sepatu & 10 & 15 & 20 & - \\
Setil alkohol & 5 & 5 & 5 & 5 \\
Isopropil miristat & 5 & 5 & 5 & 5 \\
Propil paraben & 0,05 & 0,05 & 0,05 & 0,05 \\
Metil paraben & 0,15 & 0,15 & 0,15 & 0,15 \\
Setrimonium klorida & 4 & 4 & 4 & 4 \\
Steareth-20 & 2 & 2 & 2 & 2 \\
Natrium metabisulfite & 0,10 & 0,10 & 0,10 & 0,10 \\
Parfum & Qs & Qs & Qs & Qs \\
Air suling & ad 100 g & ad 100 g & ad 100 g & ad 100 g \\
\hline
\end{tabular}

\section{Pembuatan sediaan creambath ekstrak} etanol daun kembang sepatu

Pembuatan creambath ekstrak daun kembang sepatu dimulai dari semua komponen minyak (setil alkohol, isopropil miristat, propil paraben) dicampur ke dalam cawan penguap kemudian dileburkan di atas penangas air pada suhu $75-80^{\circ} \mathrm{C}$ (fase minyak). Semua komponen air (metil paraben, setrimonium klorida, dan steareth-20) dimasukkan ke dalam bekker glass kemudian dipanaskan dengan air pada suhu $75^{\circ} \mathrm{C}$ (fase air). Fase minyak dimasukkan kedalam fase air sedikit demi sedikit sambil diaduk dalam mortir sambil digerus dengan pengadukan konstan hingga didapatkan basis creambath yang homogen. Dinginkan hingga suhu kamar. Kemudian ditambahkan ekstrak daun kembang sepatu aduk hingga homogen. Setelah itu tambahkan parfum qs aduk hingga homogen.

\section{Uji pH}

Pengukuran $\mathrm{pH}$ dilakukan dengan cara mencelupkan $\mathrm{pH}$ meter ke dalam sediaan creambath dari ekstrak etanol daun kembang sepatu (Amelia et al 2016).

Uji homogenitas.

Hasil evaluasi homogenitas creambath formula 1 , formula 2 , formula 3 , dan formula 4 menunjukkan hasil yang homogen karena tidak terlihat adanya sebaran partikel kasar pada kaca objek.

Uji viskositas.

Uji viskositas sediaan creambath menggunakan alat Viscotester VT-03F dengan spindel yang terendam dalam larutan uji.

\section{Uji daya lekat}

Uji daya lekat diharapkan memiliki waktu daya lekat yang lama sehingga sediaan creambath memiliki waktu kontak pada kulit punggung kelinci lama. 


\section{Cycling test.}

Sediaan creambath disimpan pada suhu $4^{\circ} \mathrm{C}$ selama 24 jam, lalu keluarkan dan ditempatkan pada suhu $40^{\circ} \mathrm{C}$ selama 24 jam. Waktu penyimpanan 2 suhu tersebut dianggap 1 siklus. Percobaan ini dilakukan sebanyak 6 siklus dan dievaluasi sediaannya pada awal dan akhir tes siklus.

\section{Uji aktivitas pertumbuhan rambut}

Creambath ekstrak etanol daun kembang sepatu diuji aktivitas pertumbuhan rambut menggunakan 6 kelinci jantan putih galur New Zealand White yang berumur 4-5 bulan dengan bobot 1,5-2 kg kelinci diadaptasi selama 1 minggu. Bulu pada bagian punggung kelinci di bagi menjadi 2 bagian kanan dan kiri, dicukur dan di wax membentuk persegi dengan ukuran $5 \times 5 \mathrm{~cm}$. Sebelum dioleskan dengan creambath ekstrak etanol daun kembang sepatu kulit punggung kelinci dibersihkan dengan kapas yang dibasahi air. Pengolesan dan pemijatan dilakukan 2 kali sehari pada waktu pagi dan sore selama 15 hari. Pemijatan dilakukan selama 5 menit, didiamkan selama 15 menit kemudian dibilas dengan air. Pengamatan pertumbuhan rambut kelinci dilakukan pada hari ke 3, 6, 9, 12 dan 15 dengan cara mencabut 5 helai rambut kelinci secara acak kemudian diukur menggunakan jangka sorong. Hari ke 15 rambut kelinci seluas $2 \mathrm{~cm}^{2}$ dicukur dan timbang bobot rambut kelinci dengan timbangan analitik (Sona 2018).

\section{Hasil Dan Pembahasan}

Hasil uji pH creambath.

Derajat keasaman atau $\mathrm{pH}$ dapat menjadi parameter dalam menentukan stabilitas suatu sediaan. Pengamatan $\mathrm{pH}$ dilakukan selama empat minggu. Pengukuran $\mathrm{pH}$ dilakukan dengan menggunakan $\mathrm{pH}$ meter.

Tabel 2. Hasil pemeriksaan pH sediaan creambath ekstrak daun kembang sepatu

\begin{tabular}{llllll}
\hline Waktu & $\begin{array}{l}\text { Konsentrasi } \\
10 \% \pm \mathrm{SD}\end{array}$ & $\begin{array}{l}\text { Konsentrasi } \\
15 \% \pm \mathrm{SD}\end{array}$ & $\begin{array}{l}\text { Konsentrasi } \\
20 \% \pm \mathrm{SD}\end{array}$ & $\begin{array}{l}\text { Kontrol } \\
\pm \mathrm{SD}\end{array}$ & $\begin{array}{l}\text { Produk di } \\
\text { pasaran } \pm \text { SD }\end{array}$ \\
\hline Minggu 1 & $5,30 \pm 0,00$ & $5,69 \pm 0,01$ & $5,74 \pm 0,01$ & $4,00 \pm 0,00$ & $3,95 \pm 0,04$ \\
Minggu 2 & $5,37 \pm 0,00$ & $5,70 \pm 0,00$ & $5,75 \pm 0,03$ & $4,00 \pm 0,00$ & \\
Minggu 3 & $5,37 \pm 0,00$ & $5,70 \pm 0,01$ & $5,75 \pm 0,01$ & $4,00 \pm 0,00$ & \\
Minggu 4 & $5,37 \pm 0,00$ & $5,70 \pm 0,02$ & $5,75 \pm 0,01$ & $4,00 \pm 0,00$ & \\
\hline
\end{tabular}

Nilai $\mathrm{pH}$ tidak boleh terlalu asam karena dapat menyebabkan iritasi kulit dan tidak boleh terlalu basa karena dapat menyebabkan kulit bersisik (Arief 2008). Hasil pengukuran $\mathrm{pH}$ awal sediaan creambath $(4,00-$ $5,75)$ ternyata $\mathrm{pH}$ masih berada di dalam kisaran $\mathrm{pH}$ balance sebab nilai $\mathrm{pH}$ untuk kulit normal antara 4,0-6,5 (Schueller 1999). Hasil pengukuran $\mathrm{pH}$ pada tabel 12 tiap formula berbeda karena pengaruh dari banyaknya ekstrak daun kembang sepatu. Ekstrak daun kembang sepatu mengandung alkaloid (Amelia et al. 2016), dimana alkaloid memiliki sifat basa (Helena 2015). Nilai pH yang paling banyak adalah formula dengan konsentrasi $20 \%$ yang jumlah ekstrak daun kembang sepatu paling banyak dari formula lainnya. Penyimpanan creambath ekstrak daun kembang sepatu selama empat minggu $\mathrm{pH}$ creambath mengalami kenaikan $\mathrm{pH}$ tetapi masih dalam kisaran $\mathrm{pH}$ balance.

Pengukuran $\mathrm{pH}$ merupakan salah satu parameter penting dalam analisa pada sediaan kosmetik, karena $\mathrm{pH}$ dari kosmetik yang dipakai dapat mempengaruhi daya absorbsi kulit. $\mathrm{pH}$ yang sangat tinggi atau sangat rendah pada suatu sediaan kosmetik dapat meningkatkan daya absorbsi kulit sehingga menyebabkan kulit teriritasi.

\section{Hasil uji homogenitas creambath.}

Uji homogenitas merupakan salah satu parameter penting dalam sediaan creambath, karena untuk mengetahui apakah zat aktif telah terdistribusi secara homogen di dalam basis atau belum. 


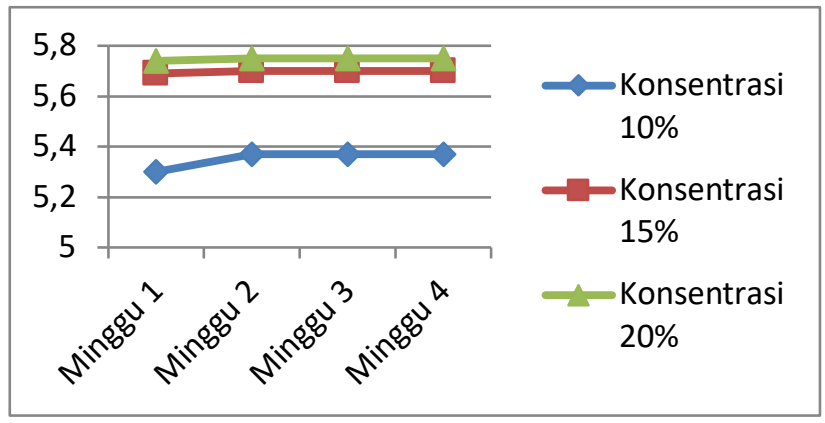

Gambar 1. Grafik hasil pH creambath ekstrak daun kembang sepatu

Tabel 3. Hasil uji homogenitas creambath ekstrak daun kembang sepatu

\begin{tabular}{lllll}
\hline \multirow{2}{*}{ Formula } & \multicolumn{4}{c}{ Homogenitas } \\
\cline { 2 - 5 } & Minggu 1 & Minggu 2 & Minggu 3 & Minggu 4 \\
\hline Konsentrasi 10\% & Homogen & Homogen & Homogen & Homogen \\
Konsentrasi 15\% & Homogen & Homogen & Homogen & Homogen \\
Konsentrasi $20 \%$ & Homogen & Homogen & Homogen & Homogen \\
Kontrol - & Homogen & Homogen & Homogen & Homogen \\
\hline
\end{tabular}

Keempat formula menghasilkan homogenitas yang baik ditandai dengan tidak adanya partikel kasar pada saat pengamatan pada objek glass. Hal ini sangat penting karena untuk kenyamanan dalam penggunaan sediaan creambath, harus tidak ada partikel atau butiran kasar yang ada pada sediaan. Hal tersebut tidak membuat kulit kepala sakit pada saat digunakan. Pengamatan uji homogenitas juga tidak terjadi gradasi warna yang artinya sediaan tersebut homogen.

\section{Hasil uji viskositas creambath.}

Viskositas secara tidak langsung berpengaruh terhadap pelepasan zat aktif didalam sediaan. Viskositas yang tinggi akan memberi gaya tahan yang besar, karena viskositas menunjukkan suatu pernyataan tahanan dari suatu cairan yang mengalir. Lamanya sediaan tertahan di tempat aplikasi, maka absorbsi zat aktif semakin bagus, sehingga efektivitas terapinya semakin baik.

Tabel 4. Hasil pengukuran viskositas sediaan creambath ekstrak daun kembang sepatu

\begin{tabular}{clllll}
\hline \multirow{2}{*}{$\begin{array}{c}\text { Sediaan } \\
\text { creambath }\end{array}$} & $\begin{array}{c}\text { Konsentrasi } \\
10 \%\end{array}$ & Konsentrasi $15 \%$ & $\begin{array}{c}\text { Konsentrasi } \\
20 \%\end{array}$ & $\begin{array}{c}\text { Kontrol } \\
-\end{array}$ & $\begin{array}{c}\text { Produk di } \\
\text { pasaran }\end{array}$ \\
\hline Minggu 1 & $27 \pm 0,00$ & $18,67 \pm 0,47$ & $14,33 \pm 0,47$ & $50 \pm 0,00$ & $70 \pm 0,00$ \\
Minggu 2 & $27,5 \pm 0,00$ & $22 \pm 0,00$ & $15 \pm 0,00$ & $62 \pm 0,00$ & \\
Minggu 3 & $28 \pm 0,00$ & $24 \pm 0,00$ & $16 \pm 0,00$ & $69 \pm 0,00$ & \\
Minggu 4 & $30 \pm 0,00$ & $25 \pm 0,00$ & $20 \pm 0,00$ & $70 \pm 0,00$ & \\
\hline
\end{tabular}

Pengujian viskositas creambath menggunakan metode Viskometer VT-03F, dari tabel di atas diketahui bahwa viskositas sediaan creambath semakin menurun dengan bertambahnya konsentrasi ekstrak daun kembang sepatu yang digunakan. Penurunan viskositas dengan kenaikan konsentrasi ekstrak dikarenakan dari bentuk ekstrak daun kembang sepatu berbentuk agak cair sehingga viskositas menurun. Selama penyimpanan viskositas mengalami kenaikan hal ini dikarenakan bentuk sediaan creambath mengalami sedikit memadat. Akibat dari penyusutan kadar air selama penyimpanan, karena pengaruh suhu yang panas (Kuncari et al 2014). 


\section{Hasil uji daya lekat creambath.}

Uji daya lekat bertujuan untuk mengetahui kemampuan creambath melekat dan melapisi permukaan kulit kepala agar dapat berfungsi secara optimal. Semakin besar nilai daya lekat maka semakin besar difusi obat karena ikatan yang terjadi antara creambath dan kulit semakin lama. Krim yang baik mampu menjamin waktu kontak yang efektif dengan kulit sehingga tujuan penggunaan tercapai, namun tidak terlalu lengket ketika digunakan.

Sediaan creambath ekstrak daun kembang sepatu untuk semua formula menghasilkan daya lekat kurang dari 1 detik. Hasil tersebut agar mudah tercuci pada saat pembilasan setelah pemakaian pada kulit kepala dan tidak meninggalkan sediaan creambath pada kulit kepala, jika pada saat pembilasan tidak bersih akan menyebabkan munculnya ketombe pada kulit kepala. Hasil uji daya lekat kurang dari 1 detik karena viskositas rendah dan sediaan creambath memiliki tipe krim minyak dalam air.

\section{Uji cycling test.}

Uji cycling test dilakukan dengan menyimpan creambath pada dua suhu yang berbeda untuk melihat pengaruh suhu terhadap pemisahan fase krim. Creambath yang baik tidak akan memisah jika disimpan pada berbagai suhu yang berbeda.

Hasil uji stabilitas menunjukkan bahwa sesudah dilakukan 6 siklus pengujian terlihat semua formula tidak menunjukkan pemisahan fase sehingga semua sediaan creambath stabil dengan penyimpanan di berbagai suhu ruang penyimpanan yang ditandai dengan tidak saling memisahnya antara fase minyak dan fase air. Suhu $4^{\circ} \mathrm{C}$ fase air akan membeku dan cenderung menyusut sehingga terjadi penyempitan ruang fase air dan menyebabkan globul minyak saling berdekatan atau cenderung bergabung membentuk ikatan antar partikel yang lebih rapat yang berakibat kekentalan sediaan menjadi meningkat. Suhu $40^{\circ} \mathrm{C}$ kristal akan mencair dan akan kembali menyebar pada sistem.

\section{Tabel 5. Hasil uji cycling test creambath} ekstrak daun kembang sepatu

\begin{tabular}{|c|c|}
\hline Sebelum cycling test & Sesudah cycling test \\
\hline Tidak memisah & Tidak memisah \\
\hline
\end{tabular}

\section{Hasil uji aktivitas pertumbuhan rambut creambath}

Pengujian aktivitas pertumbuhan rambut terhadap rambut kelinci menggunakan 2 parameter yaitu rata-rata panjang rambut dan bobot rambut kelinci. Sampel yang diujikan adalah formula creambath (formula 1, formula 2, formula 3, formula 4) dan kontrol positif. Creambath dari masing-masing formula dioleskan sebanyak 0,5 gram dan untuk kontrol positif sebanyak 5 tetes ke punggung kelinci yang telah dicukur selama 15 hari pagi dan sore, kemudian diamati pertumbuhan rambut. Hari ke 3, 6, 9, 12, dan 15 rambut dicabut secara acak sebanyak 5 helai, kemudian diukur menggunakan jangka sorong dan pada hari ke 15 rambut kelinci dicukur kemudian ditimbang.

Hasil penelitian Abraham et al (2009) laju pertumbuhan berkisar antara 0,03 sampai 0,045 $\mathrm{mm}$ per hari. Sehingga pada hasil penelitian ini dapat disimpulkan bahwa creambath ekstrak daun kembang sepatu dapat mempercepat pertumbuhan rambut. Bukti dapat mempercepat pertumbuhan rambut yaitu pada hasil laju pertumbuhan rambut lebih dari $0,03-0,045 \mathrm{~mm}$. Hari ke 15 tersebut panjang rambut yang paling tinggi adalah kontrol positif sebesar $10,94 \mathrm{~mm}$ dan paling rendah adalah kontrol negatif sebesar 4,90

$\mathrm{mm}$.

Tabel 6. Rata-rata panjang rambut

\begin{tabular}{lrrrrr}
\hline \multirow{2}{*}{ Kelompok } & \multicolumn{5}{c}{ Rata-rata panjang rambut \pm SD } \\
\cline { 2 - 6 } & Hari 3 & Hari 6 & Hari 9 & Hari 12 & Hari 15 \\
\hline Konsentrasi 10\% & $1,14 \pm 0,16$ & $2,75 \pm 0,15$ & $4,26 \pm 0,13$ & $5,60 \pm 0,16$ & $6,84 \pm 0,13^{\mathrm{ab}}$ \\
Konsentrasi 15\% & $1,50 \pm 0,22$ & $2,82 \pm 0,21$ & $4,77 \pm 0,20$ & $6,65 \pm 0,22$ & $8,28 \pm 0,25^{\mathrm{ab}}$ \\
Konsentrasi 20\% & $2,26 \pm 0,20$ & $3,60 \pm 0,23$ & $5,58 \pm 0,36$ & $7,12 \pm 0,21$ & $9,70 \pm 0,32^{\mathrm{ab}}$ \\
$\mathrm{K}-$ & $0,86 \pm 0,10$ & $1,52 \pm 0,23$ & $2,71 \pm 0,13$ & $3,85 \pm 0,09$ & $4,90 \pm 0,12^{\mathrm{b}}$ \\
$\mathrm{K}+$ & $2,75 \pm 0,24$ & $4,66 \pm 0,25$ & $7,09 \pm 0,30$ & $8,85 \pm 0,40$ & $10,94 \pm 0,43^{\mathrm{a}}$ \\
\hline
\end{tabular}

a / berbeda signifikan terhadap kontrol negatif

b / berbeda signifikan terhadap kontrol positif 


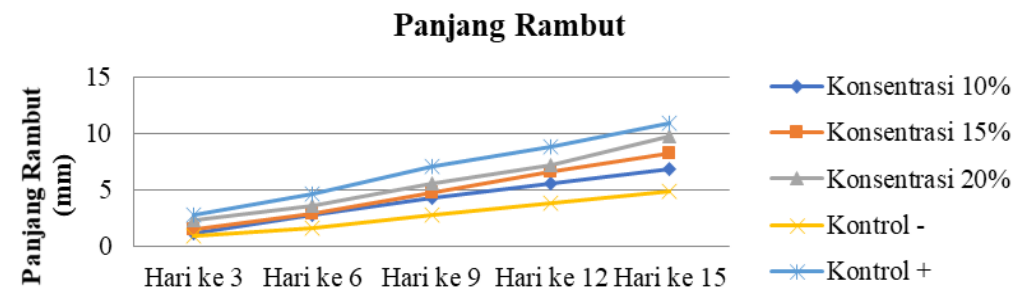

Gambar 2. Grafik hubungan antara panjang rambut $(\mathrm{mm})$ dan hari pengamatan karena pengaruh pemberian creambath ekstrak daun kembang sepatu.

Tabel 7. Bobot rambut

\begin{tabular}{lllll}
\hline \multicolumn{5}{c}{ Bobot rambut (mg) } \\
\hline Konsentrasi 10\% & Konsentrasi 15\% & Konsentrasi 20\% & K- & K+ \\
\hline 38,4 & 70,9 & 101,9 & 40,9 & 198,9 \\
\hline
\end{tabular}

\section{Kesimpulan}

Kesimpulan yang dapat diambil dari penelitian ini adalah pertama, sediaan creambath ekstrak daun kembang sepatu konsentrasi $10 \%$, $15 \%$, dan $20 \%$ mempunyai aktivitas dalam mempercepat pertumbuhan rambut kelinci (New Zealand). Kedua sediaan creambath dengan konsentrasi ekstrak daun kembang sepatu (Hibiscus rosa-sinensis L.) $20 \%$ mempunyai efek lebih besar dalam mempercepat pertumbuhan rambut kelinci dibanding dengan konsentrasi $10 \%$ dan $15 \%$ tetapi tidak sebaik kontrol positif.

\section{Daftar Pustaka}

Amelia et al. 2016. Uji Akvitas dan Keamanan Hair Tonic Ekstrak Daun Kembang Sepatu (Hibiscus rosa-sinensis) Pada Pertumbuban Rambut Kelinci. Jurnal Farmasi Indonesia vol. 8.

Arief, M. 2008. Pengantar Metodologi Penelitian untuk. Ilmu Kesehatan. Surakarta

Helena, L. 2015. Identifikasi Senyawa Bahan Alam Tumbuhan Babadotan. Universitas Padan
Jadhav VM, Thorat RM, Kadam VJ, Sathe NS. 2009. Traditional medicinal uses of Hibiscus rosasinensis

Kumar A \& Singh A. Review on Hibiscus rosasinensis. International J Res Pharmaceut Biomed Sci 2012; 3(2): 534-538.6.

Kuncari, E.S, Iskandarsyah, dan Praptiwi. 2014. Evaluasi Uji Stabilitas dan Sineresis Sediaan Gel yang Mengandung Minoksidil, Apigenin, dan Perasan Herba Seledri (Apium graveolens L.). UI Depok, Jakarta.

Pathan A, Pathan M, Garud A. 2012. Effect of Hibiscus rosa-sinensis, Calotropis gigantea and polyherbal formulation on stress induced alopecia. IJPI; 2(6): 20-29.

Schuller, R, dan Romanowski, P. 1999. Conditioning Agents for Hair and Skin. New York: Marcel Dekker Inc.

Yuswantina R, Yulianta OW, Fitri Z. 2013. Efek ekstrak daun talok (Muntingia calabura L.) terhadap daya tumbuh rambut kelinci jantan galur Australia. Semarang. Program Studi Farmasi, STIKES Ngudi Waluyo 